\section{Medicine under capitalism}

\author{
John Launer
}

For about ten years, I have carried out annual appraisals on doctors working in general practice. I do this on a freelance basis, not as part of my salaried work. When I started, I used to claim my fees from a man called Steve, in an office at the local primary care trust. Now Steve is no longer there. Nor is his job, nor his office, nor the trust. Nowadays, I send my invoices to an agency a couple of hundred miles away called 'Shared Business Services Payables.' When I write the invoices, I have to use a 'supplier number', identifying myself as a private business supplying services to the National Health Service (NHS). I also have to include my 'purchase order number', confirming that the NHS has agreed to purchase those services. My personal contribution as an appraiser has effectively been absorbed into the same system that deals with the supply of X-ray machines, hospital beds, or toilet rolls.

This change of my identity-from an individual professional to a business-is no random event. It is one small part of an intentionally designed change in the public services in England. It reflects an ideological shift that has taken place over the last couple of decades, in the name of the political and economic movement known as neo-liberalism. A generation ago, anyone in the health service who used terms like supplier, purchasers, providers, competition, market, profit, efficiency or output would have been regarded as exceedingly strange. Now it has become our everyday language. In England, and in many other countries, medicine has moved from a welfare model to a capitalist one. Private companies are taking over an increasing proportion of services, even if these are still branded as part of a public system. In keeping with this, the language of the welfare state has been replaced by one of commerce and capitalism.

In a book entitled 'Capitalist Realism', the cultural commentator Mark Fisher has examined how this process has taken

Correspondence to: Dr John Launer, Faculty Development, Health Education England, Stewart House, 32 Russell, London WC1B 5DN, UK; john.launer@nwl.hee.nhs.uk place. ${ }^{1}$ He suggests that, since the fall of communist regimes in the 1980 s, capitalism has successfully come to present itself around the whole world as the only feasible political and economic system. $\mathrm{He}$ demonstrates how politicians, bureaucracies, education, books and movies all now speak with a single voice. It is a voice that says that everything, including medicine and education, should be run like a business. 'For most people under twenty in Europe and North America', he writes, 'the lack of alternatives to capitalism is no longer even an issue. Capitalism seamlessly occupies the horizons of the thinkable.' As a result, things that seemed impossible in the past-like the privatisation of public services-are presented as natural and inevitable, while alternative models of society are rendered unimaginable. Alterations in language are a significant part of how this happens.

\section{WEALTH INEQUALITY}

Fisher's critique of neo-liberalism has been influential, but another recent publication has been devastating in its analysis of modern capitalism and its effects. Last year, the French economist Thomas Piketty leaped from relative academic obscurity to worldwide fame with his book 'Capital in the Twenty-First Century'. ${ }^{2}$ His focus is on wealth inequality-the widening gap between the poorest in society and the ultra-rich. The facts of inequality are staggering. The top three per cent of families in the United States now hold double the wealth of all the poorest 90 per cent of their nation put together. By next year, one per cent of the world's population will own half its wealth. In theory, modern capitalism should have benefitted everyone by raising the standard of living across the board, and providing incentives for enterprise. In practice, Piketty argues, this simply does not happen. He and his team have used data from two centuries and twenty countries, to demonstrate that economies expand quite slowly, while the return on investments rises at four or five times the rate. The gap between those who have wealth and those who do not is therefore continually widening. The winners of the game may claim that they have earned their fortunes and power legitimately, through taking risks and making sound business choices, but the losers are left with a diminishing share of income and wealth, and are increasingly depicted as failures and undeserving.

The pictures painted by both Fisher and Piketty are not cheerful ones. Fisher describes the demoralisation of young people who are unable to imagine earning any significant wealth during their lives, in a world where nothing else is seen as carrying any value. Piketty warns of the risk that a tiny elite of high-income and highwealth individuals will capture the political process, threatening our democratic institutions and values. Both produce evidence of these developments. At the same time, they also point to remedies. In Fisher's view, it is a matter of raising people's consciousness, and helping them to become aware that the discontent they feel with their lives is a symptom not of personal insecurity, but of dysfunction and false values in the society around them. Piketty argues that governments can and should intervene to correct the inevitable injustices of capitalism, through progressive taxes and other means of wealth distribution.

There is no particular reason why doctors and other health professionals, as distinct from anyone else, should be taken up with these issues-except that the business model challenges some of the core values of medicine. In terms of language, the word 'output' is not the same as 'care': it creates a particular attitude to patients, turning them into objects instead of persons. Fragmenting care among different services leads to poor communication and the loss of teamwork. For example, receiving X-ray results from a call centre abroad, simply because this is cheaper, carries far greater risks to patient safety compared to discussing these with colleagues in the same hospital who know and understand the clinical context. Outsourcing health care to businesses may lead to poor performance or-if profits fall-to private companies deciding to pull out. ${ }^{3}$ Most important of all, the wealth inequality that comes with modern capitalism is not an incidental nuisance as far as medicine is concerned. It is one of the principal determinants of ill health. ${ }^{4}$ These developments 


\section{On reflection}

are not inevitable. Challenging them at any level-whether as language, practice or policy-may be a professional duty as much as a political choice.

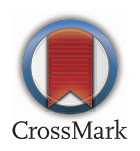

To cite Launer J. Postgrad Med J 2015;91:239-240. Postgrad Med J 2015;91:239-240.

doi:10.1136/postgradmedj-2015-133347

\section{REFERENCES}

1 Fisher M. Capitalist realism: Is there no alternative? London: Zero Books, 2009.
2 Piketty T. Capital in the twenty-first century. Harvard: Harvard University Press, 2014.

3 lacobucci G. Outsourcing the NHS. BMJ 2015;350: h875.

4 Marmot M, Wilkinson R. eds. Social determinants of health, 2nd edition. Oxford: Oxford University Press, 2005. 